\title{
Copepod communities related to water masses in the southwest East China Sea
}

\author{
Li-Chun Tseng $\cdot$ Sami Souissi $\cdot$ Hans-Uwe Dahms $\cdot$ \\ Qing-Chao Chen $\cdot$ Jiang-Shiou Hwang
}

Received: 11 June 2007 / Revised: 5 December 2007 / Accepted: 5 December 2007 / Published online: 10 January 2008

(C) Springer-Verlag and AWI 2007

\begin{abstract}
The East China Sea is characterized by a complex hydrographic regime and high biological productivity and diversity. This environmental setting in particular challenged a case study on the use of mesozooplankton community parameters as indicators of water masses. In order to reveal spatial patterns of zooplankton communities during summer, a large scale oceanic transect study was conducted. Two transects were taken in the southwest East China Sea region, covering for the first time the China shelf, slope, and the estuaries of the Yangtze river and of the Minjiang river, the northern Taiwan Strait, and the Kuroshio Current region. A total of 77 copepod species were quantified. Copepod abundance was significantly higher in the estuary of the Yangtze River runoff mixture waters and lowest at the Kuroshio Current Region. The calanoid Parvocalanus crassirostris was the most frequently occurring and abundant species retrieved from 27 samples of a total of 39 samples. The use of multivariate cluster analysis separated the Mainland China Shelf from the northern Taiwan Strait and the Kuroshio Current Region at
\end{abstract}

Communicated by H.-D. Franke.

L.-C. Tseng · H.-U. Dahms · J.-S. Hwang $(\square)$

Institute of Marine Biology,

National Taiwan Ocean University,

Keelung 202, Taiwan

e-mail: Jshwang@mail.ntou.edu.tw

S. Souissi

CNRS - FRE 2816 ELICO,

Université des Sciences et Technologies de Lille-Lille1,

Station Marine, 28 Avenue Foch, 62930 Wimereux, France

Q.-C. Chen

South China Sea Institute of Oceanology,

Chinese Academy of Science, Guangzhou, China the first hierarchical level. The use of an indicator value method (IndVal) associated with each cluster of stations revealed characteristic species assemblages. Two hierarchical levels defined 4 assemblages within geographical sectors representing copepod assemblages of the Kuroshio Current Region, of the northern Taiwan Strait and the southern China Shelf near the estuary of the Minjiang River and northern stations near the estuary of the Yangtze River. Overall, there was a strong correspondence between the distribution of certain copepod species and water masses. Differences between the Mainland China shelf, the northern Taiwan Strait and the Kuroshio Current Region were characterized by differences in species composition and abundance. Water mass boundaries in the study area were exclusively indicated by distinct differences in species composition, emphasizing a correlation between copepod communities and water masses of the southwest East China Sea in summer.

Keywords Copepod composition - Water mass . East China Sea · Taiwan Strait · Kuroshio Current

\section{Introduction}

The present study was carried out within a long-term project "Long-term Observation and Research of the East China Sea (ECS) (I) -Factors Controlling Carbon Fluxes (LORECS)". The west border of the East China Sea to the mainland of China links with the Yellow Sea in the north and with the Taiwan Strait (TS) in the south. Water masses passing the Kuroshio Current region (KCR) along the east coast of Taiwan flow northward (Ashjian et al. 2005; Shahidu Islam et al. 2006). There are many rivers carrying the largest runoff of low-saline water to the East China Sea 
from the mainland of West China (Liu et al. 2000), e.g. the Yangtze River, Qiantang River, Minjiang River and Wujiang River. The annual seawater temperature is primarily influenced by the monsoons and mediated by ocean currents. In summer, the sea surface water temperature is nearly homogeneous at about $27-29^{\circ} \mathrm{C}$ and is influenced by the Yangtze River, where a low-saline high-thermal water tongue is sometimes entering the estuarine regions (Chen 1992).

Zooplankton communities support higher trophic levels and copepods are an important determinant as for their abundance and ecological roles (Turner 1998; Hwang et al. 1998; Wong et al. 1998). In the upwelling of the Kuroshio Current and in the East China Sea near to Taiwan copepods are the most abundant constituents of mesozooplankton communities (Chen and Chen 1992). Investigating copepod community structure and distribution patterns appears therefore as an essential step towards the understanding of the trophic ecology of pelagic systems (Chen 1992).

Compared to other oceanographic regions, there have been only a few studies on copepod ecology in the East China Sea (Chen and Zhang 1965; Tan 1967; Chen et al. 1974; Chen and Chen 1992; Shih and Young 1995; Shih and Chiu 1998; Lan et al. 2004; Hwang and Wong 2005; Hwang et al. 2006). Planktonic copepods in upwelling regions of the southern East China Sea have been studied previously (Shih et al. 2000; Lo et al. 2004). Several studies have been published on the biological oceanography of the East China Sea area, including zooplankton composition (Chen 1992), copepod transport by monsoon driven currents (Hwang and Wong 2005; Hwang et al. 2006), chlorophyll $a$ (Chang et al. 2003a; Gong et al. 2000; Gong and Liu 2003), primary productivity in correlation with chemical hydrography (Gong et al. 1996, 2000), photosynthetic-irradiance models (Gong et al. 2001), primary production (Gong and Liu 2003), cyanobacteria (Chiang et al. 2002; Chang et al. 2000, 2003b), nutrient fluxes (Liu et al. 2000), carbon cycling (Chang et al. 2003a; Shiah et al. 2003), and potential anthropogenic impacts (Hwang et al. 2004). Previous publications suggest a correlation between temporal and spatial distribution patterns of zooplankton that affect the dynamics of biological and chemical interactions (Berasategui et al. 2006). In the present paper, the spatial distribution of copepods in the southwest ECS and in summer was examined for the first time. The present study provides additional and new information on the composition, structure and dynamics of copepod communities in relation to water masses of estuaries and rivers in general and those of the ECS, the shelf of mainland China, the northern Taiwan Strait (NTS) and the Kuroshio Current water masses in particular.

\section{Materials and methods}

Field sampling

The area of investigation in the southwest ECS (Fig. 1) is a border region of mainland China adjacent to the NTS and Taiwan. We set up 13 stations along two perpendicular transects and sampled mesozooplankton during cruise 618 of Ocean Research Vessel I of the National Science Council of Taiwan (Republic of China) from 15 to 29 July 2001. A transect line with 8 stations was chosen north of the estuary of Yangtze River (EYR) towards the southern estuary of the estuary of Minjiang River (EMR). A second transect line with five stations was located near the western EMR through the NTS east of KCR. The locations of stations are shown in Fig. 1 and details are shown in Table 1. Copepods were collected from the seabed to the surface at all stations in oblique hauls by $100 \mu \mathrm{m}$ mesh nets. Tow speed was set at $33-50 \mathrm{~cm} \mathrm{~s}^{-1}$. Seabed depths of stations 12 and 13 were $577 \mathrm{~m}$ and $1,760 \mathrm{~m}$, respectively — but samples were taken only above $150 \mathrm{~m}$ water depth. Since the copepod composition is known to change diurnally, samples were taken every $6 \mathrm{~h}$ at four stations with the following specificities: EYR (six samples, $20 \mathrm{~m}$ vertical net tow), EMR (eight samples, $10 \mathrm{~m}$ vertical net tow), NTS (eight samples, $60 \mathrm{~m}$ vertical net tow), and KCR (eight samples, $150 \mathrm{~m}$ vertical net tow). The water volume filtered was estimated from flow

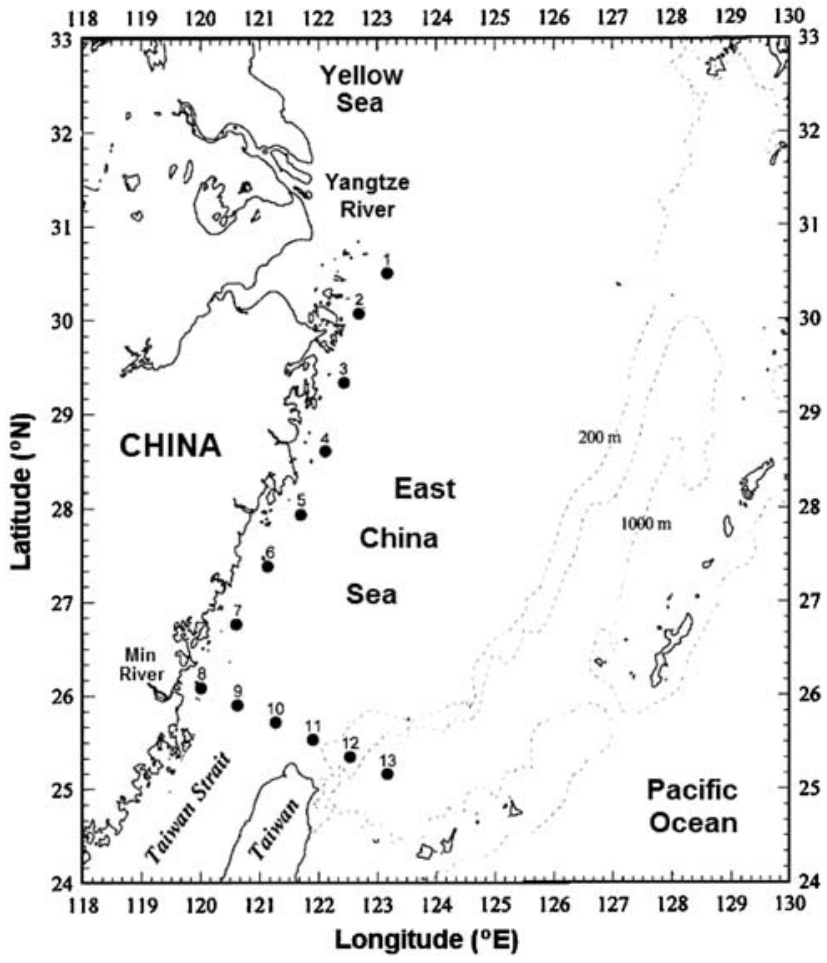

Fig. 1 Map of the sampling stations of LORECS OR1 618, 15-29 July 2001 
Table 1 Locations, dates, times, sampling depths, and CTD data collected at LORECS OR1 CR-618 stations

\begin{tabular}{lllllc}
\hline Station & $\begin{array}{l}\text { Latitude } \\
(\mathrm{N})\end{array}$ & $\begin{array}{l}\text { Longitude } \\
(\mathrm{E})\end{array}$ & Date (-July 2001)/Time & $\begin{array}{l}\text { Sampling } \\
\text { depth }(\mathrm{m})\end{array}$ & $\begin{array}{l}\text { CTD data } \\
\text { depth }(\mathrm{m})\end{array}$ \\
\hline 1 & $30^{\circ} 30^{\prime}$ & $123^{\circ} 10^{\prime}$ & $\begin{array}{l}16 / 22: 00,17 / 04: 00,17 / 10: 00,17 / 16: 00, \\
17 / 22: 00,18 / 04: 00\end{array}$ & 30 & 30 \\
2 & & & $18 / 12: 50$ & 45 & 45 \\
3 & $30^{\circ} 30^{\prime}$ & $122^{\circ} 52^{\prime}$ & $18 / 18: 00$ & 25 & 25 \\
4 & $29^{\circ} 19^{\prime}$ & $122^{\circ} 25^{\prime}$ & 25 & 25 \\
5 & $28^{\circ} 36^{\prime}$ & $122^{\circ} 07^{\prime}$ & $18 / 23: 30$ & 25 & 25 \\
6 & $27^{\circ} 56^{\prime}$ & $121^{\circ} 42^{\prime}$ & $19 / 05: 00$ & 25 & 25 \\
7 & $27^{\circ} 22^{\prime}$ & $121^{\circ} 08^{\prime}$ & $19 / 10: 50$ & 30 & 30 \\
8 & $26^{\circ} 46^{\prime}$ & $120^{\circ} 36^{\prime}$ & $19 / 16: 50$ & 10 & 20 \\
& $26^{\circ} 01^{\prime}$ & $119^{\circ} 54^{\prime}$ & $22 / 16: 00,22 / 22: 00,23 / 04: 00,23 / 10: 00$, & \\
9 & & & $23 / 16: 00,23 / 22: 00,24 / 04: 00,24 / 10: 00$ & 60 & 60 \\
10 & $25^{\circ} 54^{\prime}$ & $120^{\circ} 37^{\prime}$ & $24 / 20: 45$ & 70 & 70 \\
& $25^{\circ} 43^{\prime}$ & $121^{\circ} 16^{\prime}$ & $20 / 11: 00,20 / 17: 00,20 / 23: 00,21 / 05: 00$, & & \\
11 & & & $21 / 11: 00,21 / 17: 00,21 / 23: 00,22 / 05: 00$ & & 115 \\
12 & $25^{\circ} 32^{\prime}$ & $121^{\circ} 54^{\prime}$ & $25 / 07: 00$ & 115 & 150 \\
13 & $25^{\circ} 20^{\prime}$ & $122^{\circ} 32^{\prime}$ & $25 / 11: 30$ & 150 & 150 \\
& $25^{\circ} 10^{\prime}$ & $123^{\circ} 10^{\prime}$ & $25 / 17: 00,25 / 23: 00,26 / 05: 00,26 / 11: 00$, & 150 &
\end{tabular}

indicator value index (IndVal) proposed by Dufrêne and Legendre (1997) as in Souissi et al. (2001) and Anneville et al. (2002). This index is obtained by multiplying twoindependent information: specificity measures (measure of affiliation) and fidelity (measure of occurrence) of a species for a group. The species characterizing a group best is indicated by a high IndVal. For the present study, only species having an indicator value greater than the arbitrary threshold level of $25 \%$ were retained in the assemblage. Furthermore, the characteristic species for each hierarchical level, showing the maximal value of their IndVal in that category are pointed out (Dufrêne and Legendre 1997). Different steps of the cluster analysis and the graphical representation were programmed using Matlab Software (ver. 6.1).

\section{Results}

Faunistic peculiarities

From 39 samples we found 77 copepod species belonging to 43 genera and 25 families: 54 species of Calanoida, 6 species of Cyclopoida, 4 species of Harpacticoida, and 13 species of Poecilostomatoida (Table 2). There were 24 species present in ten or more samples but 13 species occurred only once. The ten most abundant and common species were Parvocalanus crassirostris (Dahl, 1893), Oithona nana Giesbrecht, 1892, Paracalanus parvus (Claus, 1863), Euterpina acutifrons (Dana, 1847), Paracalanus nanus Sars, 1907, Corycaeus (Ditrichocorycaeus) affinis McMurrich, 1916, Paracalanus aculeatus Giesbrecht, 1888, Oithona rigida Giesbrecht, 1896, Acartia (Odontacartia) 
Table 2 Planktonic copepod species recorded during summer sampling in the East China Sea, 15-29 July 2001

\begin{tabular}{|c|c|c|c|c|c|}
\hline Copepod taxa & Abbrev. & OR & RA & Mean & SD \\
\hline \multicolumn{6}{|l|}{ CALANOIDA } \\
\hline \multicolumn{6}{|l|}{ ACARTIIDAE } \\
\hline $\begin{array}{l}\text { Acartia (Odontacartia) spinicauda } \\
\text { Giesbrecht, } 1889\end{array}$ & Acart. spin. & 41.03 & 2.70 & 100.09 & 184.62 \\
\hline Acartia negligens Dana, 1849 & Acart. negl. & 35.90 & 0.55 & 20.35 & 38.21 \\
\hline \multicolumn{6}{|l|}{ AETIDEIDAE } \\
\hline Undeuchaeta plumosa (Lubbock, 1856) & Undeu. plum. & 2.56 & 0.02 & 0.69 & 4.29 \\
\hline \multicolumn{6}{|l|}{ AUGAPTILIDAE } \\
\hline Haloptilus longicornis (Claus, 1865) & Halop. long. & 2.56 & 0.01 & 0.29 & 1.81 \\
\hline \multicolumn{6}{|l|}{ CALANIDAE } \\
\hline Calanus sinicus Brodsky, 1965 & Calan. sini. & 20.51 & 1.83 & 67.89 & 189.61 \\
\hline Canthocalanus pauper (Giesbrecht, 1888) & Canth. paup. & 61.54 & 1.42 & $\mathbf{5 2 . 4 5}$ & 63.23 \\
\hline Cosmocalanus darwini (Lubbock, 1860) & Cosmo. darw. & 20.51 & 0.13 & 4.92 & 11.07 \\
\hline Mesocalanus tenuicornis (Dana, 1863) & Mesoc. tепи. & 2.56 & 0.05 & 2.04 & 12.71 \\
\hline Nannocalanus minor (Claus, 1863) & Nanno. mino. & 12.82 & 0.07 & 2.62 & 8.18 \\
\hline Neocalanus gracilis (Dana, 1849) & Neoca. grac. & 2.56 & 0.02 & 0.66 & 4.10 \\
\hline Undinula vulgaris (Dana, 1849) & Undin. vulg. & 38.46 & 1.44 & $\mathbf{5 3 . 5 1}$ & 103.54 \\
\hline \multicolumn{6}{|l|}{ CANDACIIDAE } \\
\hline Candacia bradyi A. Scott, 1902 & Canda. brad. & 17.95 & 0.19 & 7.21 & 20.55 \\
\hline Candacia catula (Giesbrecht, 1889) & Canda. catu. & 15.38 & 0.11 & 4.02 & 12.08 \\
\hline Paracandacia truncata (Dana, 1849) & Pcand. trun. & 2.56 & 0.04 & 1.58 & 9.85 \\
\hline \multicolumn{6}{|l|}{ CENTROPAGIDAE } \\
\hline Centropages calaninus (Dana, 1849) & Centr. cala. & 7.69 & 0.03 & 1.06 & 3.82 \\
\hline $\begin{array}{l}\text { Centropages dorsispinatus Thompson } \\
\quad \& \text { Scott, } 1903\end{array}$ & Centr. dors. & 5.13 & 0.17 & 6.20 & 27.23 \\
\hline Centropages furcatus (Dana, 1849) & Centr. furc. & 10.26 & 0.06 & 2.15 & 7.11 \\
\hline \multicolumn{6}{|l|}{ CLAUSOCALANIDAE } \\
\hline Clausocalanus arcuicornis (Dana, 1849) & Claus. arcu. & 7.69 & 0.03 & 0.95 & 3.68 \\
\hline Clausocalanus furcatus (Brady, 1883) & Claus. furc. & 46.15 & 1.77 & 65.62 & 119.77 \\
\hline \multicolumn{6}{|l|}{ EUCALANIDAE } \\
\hline Mecynocera clausi Thompson, 1888 & Mecyn. clau. & 5.13 & 0.03 & 1.01 & 5.60 \\
\hline Pareucalanus attenuatus (Dana, 1849) & Peuca. atte. & 12.82 & 0.07 & 2.53 & 8.12 \\
\hline Rhincalanus rostrifrons Dana 1849 & Rhcal. rost. & 5.13 & 0.03 & 1.02 & 4.54 \\
\hline Subeucalanus crassus (Giesbrecht, 1888) & Seuca. cras. & 7.69 & 0.06 & 2.21 & 8.82 \\
\hline $\begin{array}{l}\text { Subeucalanus subcrassus } \\
\quad \text { (Giesbrecht, 1888) }\end{array}$ & Seuca. subc. & 66.67 & 2.59 & 96.07 & 136.75 \\
\hline Subeucalanus subtenuis (Giesbrecht, 1888) & Seuca. subt. & 17.95 & 0.15 & 5.67 & 14.03 \\
\hline \multicolumn{6}{|l|}{ EUCHAETIDAE } \\
\hline Euchaeta concinna (Dana, 1849) & Eucha. conc. & 64.10 & 2.15 & 79.62 & 179.29 \\
\hline Euchaeta plana Mori, 1937 & Eucha. plan. & 10.26 & 0.20 & 7.49 & 28.94 \\
\hline Euchaeta rimana Bradford, 1973 & Eucha. rima. & 5.13 & 0.13 & 4.71 & 20.82 \\
\hline \multicolumn{6}{|l|}{ HETERORHABDIDAE } \\
\hline Heterorhabdus papilliger (Claus, 1863) & Heter. papi. & 2.56 & 0.02 & 0.62 & 3.86 \\
\hline \multicolumn{6}{|l|}{ LUCICUTIIDAE } \\
\hline Lucicutia flavicornis (Claus, 1863) & Lucic. flav. & 15.38 & 0.17 & 6.42 & 17.96 \\
\hline \multicolumn{6}{|l|}{ METRIDIIDAE } \\
\hline $\begin{array}{l}\text { Pleuromamma abdominalis } \\
\text { (Lubbock, 1856) }\end{array}$ & Plmam. abdo. & 5.13 & 0.03 & 1.09 & 4.91 \\
\hline Pleuromamma gracilis (Claus, 1863) & Plmam. grac. & 10.26 & 0.08 & 2.86 & 9.88 \\
\hline
\end{tabular}


Table 2 continued

\begin{tabular}{|c|c|c|c|c|c|}
\hline Copepod taxa & Abbrev. & OR & RA & Mean & $\mathrm{SD}$ \\
\hline \multicolumn{6}{|l|}{ PARACALANIDAE } \\
\hline Acrocalanus gibber Giesbrecht, 1888 & Acala. gibb. & 12.82 & 0.23 & 8.48 & 25.50 \\
\hline Acrocalanus gracilis Giesbrecht, 1888 & Acala. grac. & 30.77 & 0.54 & 20.10 & 44.06 \\
\hline Acrocalanus monachus Giesbrecht, 1888 & Acala. mona. & 15.38 & 0.15 & 5.67 & 15.27 \\
\hline Calocalanus pavo (Dana, 1849) & Caloc. pavo. & 20.51 & 0.30 & 11.06 & 33.68 \\
\hline Calocalanus pavoninus Farran, 1936 & Caloc. pvon. & 20.51 & 0.50 & 18.48 & 54.16 \\
\hline Calocalauns plumulosus (Claus, 1863) & Caloc. plum. & 25.64 & 0.52 & 19.38 & 55.27 \\
\hline Paracalanus aculeatus Giesbrecht, 1888 & Pcala. acul. & 56.41 & 4.55 & 168.67 & 288.14 \\
\hline Paracalanus nanus Sars, 1907 & Pcala. nanu. & 64.10 & 6.07 & 224.87 & 365.03 \\
\hline Paracalanus parvus (Claus, 1863) & Pcala. parv. & 46.15 & 10.69 & 395.93 & 863.85 \\
\hline Parvocalanus crassirostris (Dahl, 1893) & Parvc. cras. & 69.23 & 16.92 & 626.88 & 1158.89 \\
\hline \multicolumn{6}{|l|}{ PONTELLIDAE } \\
\hline Calanopia elliptica (Dana, 1849) & Capia. elli. & 7.69 & 0.05 & 1.98 & 7.38 \\
\hline Calanopia minor A. Scott, 1902 & Capia. mino. & 10.26 & 0.08 & 2.96 & 11.05 \\
\hline Labidocera acuta (Dana, 1849) & & 5.13 & 0.03 & 1.18 & 5.56 \\
\hline Labidocera bipinnata Tanaka, 1936 & Labid. bipi. & 5.13 & 0.07 & 2.48 & 10.88 \\
\hline Labidocera minuta Giesbrecht, 1889 & Labid. minu. & 2.56 & 0.04 & 1.58 & 9.85 \\
\hline Pontellinna plumata (Dana, 1849) & Ponte. plum. & 5.13 & 0.07 & 2.48 & 11.18 \\
\hline \multicolumn{6}{|l|}{ SCOLECITHRICIDAE } \\
\hline Scaphocalanus echinatus Farran, 1905 & Scaph. echi. & 2.56 & 0.03 & 1.09 & 6.84 \\
\hline $\begin{array}{l}\text { Scolecithricella longispinosa } \\
\text { Chen \& Zhang, } 1965\end{array}$ & Scoll. long. & 35.90 & 2.37 & 87.73 & 289.11 \\
\hline Scolecithrix danae (Lubbock, 1856) & Scolx. dana. & 12.82 & 0.19 & 7.09 & 24.30 \\
\hline \multicolumn{6}{|l|}{ TEMORIDAE } \\
\hline Temora discaudata (Giesbrecht, 1889) & Temor. disc. & 43.59 & 0.75 & 27.80 & 49.16 \\
\hline Temora turbinata (Dana, 1849) & Temor. turb. & 17.95 & 0.33 & 12.30 & 31.78 \\
\hline \multicolumn{6}{|l|}{ TORTANIDAE } \\
\hline Tortanus gracilis (Brady, 1883) & Tortan. grac. & 2.56 & 0.02 & 0.65 & 4.04 \\
\hline \multicolumn{6}{|l|}{ CYCLOPOIDA } \\
\hline \multicolumn{6}{|l|}{ OITHONIDAE } \\
\hline Oithona attenuata Farran, 1913 & Oitho. atte. & 10.26 & 0.14 & 5.22 & 21.08 \\
\hline Oithona fallax Farran, 1913 & Oitho. fall. & 7.69 & 0.10 & 3.71 & 14.19 \\
\hline Oithona nana Giesbrecht, 1892 & Oitho. nana & 48.72 & 14.32 & 530.75 & 1238.39 \\
\hline Oithona rigida Giesbrecht, 1896 & Oitho. rigid. & 56.41 & 4.49 & 166.23 & 277.06 \\
\hline Oithona setigera (Dana, 1849) & Oitho. seti. & 23.08 & 0.35 & 13.08 & 32.16 \\
\hline Oithona similis Claus, 1866 & Oitho. simi. & 20.51 & 0.29 & 10.78 & 42.86 \\
\hline \multicolumn{6}{|l|}{ HARPACTICOIDA } \\
\hline \multicolumn{6}{|l|}{ CLYTEMNESTRIDAE } \\
\hline Clytemnestra scutellata Dana, 1847 & Clyte. scut. & 20.51 & 0.38 & 13.97 & 33.76 \\
\hline \multicolumn{6}{|l|}{ ECTINOSOMIDAE } \\
\hline Microsetella norvegica (Boeck, 1846) & Micro. norv. & 61.54 & 1.23 & 45.43 & 59.04 \\
\hline \multicolumn{6}{|l|}{ EUTERPINIDAE } \\
\hline Euterpina acutifrons (Dana, 1847) & Euter. acut. & 66.67 & 9.66 & 357.85 & 746.05 \\
\hline \multicolumn{6}{|l|}{ MACROSETELLIDAE } \\
\hline Macrosetella gracilis (Dana, 1847) & Macro. grac. & 30.77 & 0.60 & 22.08 & 64.79 \\
\hline \multicolumn{6}{|l|}{ POECILOSTOMATOIDA } \\
\hline \multicolumn{6}{|l|}{ CORYCAEIDAE } \\
\hline Corycaeus (Corycaeus) crassiusculus Dana, 1849 & Coryc. cras. & 7.69 & 0.08 & 3.08 & 13.37 \\
\hline Corycaeus (Corycaeus) speciosus Dana, 1849 & Coryc. spec. & 5.13 & 0.03 & 1.18 & 5.56 \\
\hline
\end{tabular}


Table 2 continued

\begin{tabular}{|c|c|c|c|c|c|}
\hline Copepod taxa & Abbrev. & OR & RA & Mean & SD \\
\hline $\begin{array}{l}\text { Corycaeus (Ditrichocorycaeus) affinis } \\
\text { McMurrich, } 1916\end{array}$ & Coryc. affi. & 64.10 & 5.33 & 197.39 & 368.02 \\
\hline $\begin{array}{l}\text { Corycaeus (Onychocorycaeus) pumilus } \\
\text { M. Dahl, } 1912\end{array}$ & Coryc. pumi. & 7.69 & 0.05 & 1.77 & 6.91 \\
\hline Corycaeus (Urocorycaeus) lautus Dana, 1849 & Coryc. laut. & 20.51 & 0.28 & 10.45 & 33.12 \\
\hline Farranula concinnus (Dana,1847) & Farra. conc. & 2.56 & 0.04 & 1.65 & 10.33 \\
\hline Farranula gibbula (Giesbrecht, 1891) & Farra. gibb. & 28.21 & 0.37 & 13.88 & 31.06 \\
\hline \multicolumn{6}{|l|}{ ONCAEIDAE } \\
\hline Oncaea conifera Giesbrecht, 1891 & Oncae. coni. & 25.64 & 0.79 & 29.13 & 76.47 \\
\hline Oncaea media Giesbrecht, 1891 & Oncae. medi. & 17.95 & 0.20 & 7.50 & 22.35 \\
\hline Oncaea venusta Philippi, 1843 & Oncae. vепи. & 30.77 & 0.33 & 12.41 & 32.57 \\
\hline \multicolumn{6}{|l|}{ SAPPHIRINIDAE } \\
\hline Copilia mirabilis Dana, 1849 & Copil. mira. & 2.56 & 0.03 & 1.09 & 6.84 \\
\hline Sapphirina intestinata Giesbrecht, 1891 & Sapph. inte. & 2.56 & 0.03 & 1.13 & 7.03 \\
\hline Sapphirina nigromaculata Claus, 1863 & Sapph. nigr. & 2.56 & 0.03 & 0.98 & 6.10 \\
\hline
\end{tabular}

spinicauda Giesbrecht, 1889 and Subeucalanus subcrassus, (Giesbrecht, 1888). Parvocalanus crassirostris did not only occur in 27 of 39 samples, but represented the most abundant species with an average density of 626.88 (individuals $\mathrm{m}^{-3}$ ).

\section{Hydrological structure}

Monthly-averaged information derived from advanced very high resolution radiometer (AVHRR) recordings for sea surface temperature and seawater chlorophyll $a$ values for July 2002 are shown in Fig. 2. The image for sea surface temperatures (Fig. 2a) shows the estuary of the Yangtze River with a high temperature fresh water output, providing water temperatures above $30^{\circ} \mathrm{C}$. Surrounding waters of northern Taiwan and coastal mainland China were above $29^{\circ} \mathrm{C}$. Sea surface concentration of chlorophyll $a$ (Fig. 2b) shows the highest regional distribution along the coast of the mainland of China, especially in the EYR, reaching levels above $5.0 \mathrm{mg} \mathrm{m}^{-3}$. A warmer fresh-water mass tongue $\left(>30^{\circ} \mathrm{C},<30\right.$ practical salinity unit-PSU) was found in the EYR, providing high concentrations of chlorophyll $a$ in the Yellow Sea and the north-western ECS. The chlorophyll $a$ concentration of areas from the EMR towards the NTS and the KCR were lower than along the mainland China coast, ranging between 0.5 and $1.0 \mathrm{mg} \mathrm{m}^{-3}$.

\section{CTD profiles}

The vertical profiles of temperature and salinity at each sampling station are shown in Fig. 3. The hydrography of
Fig. 2 Monthly-averaged information derived from AVHRR for sea surface temperature (a) and SeaWiFS chlorophyll $a(\mathbf{b})$ of July 2001
(A)

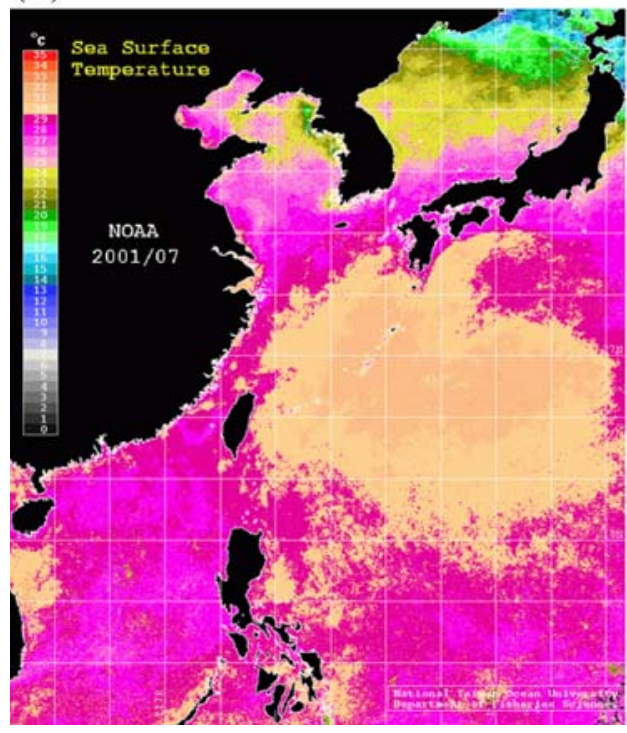

(B)

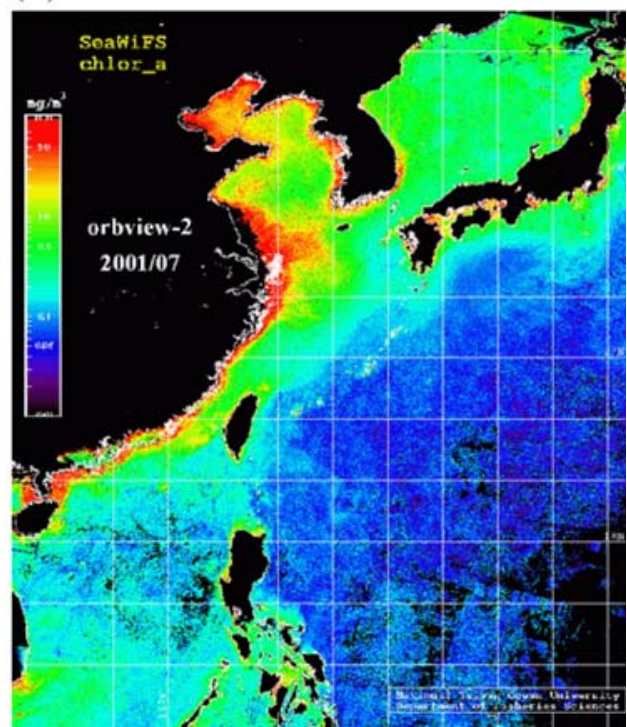


Fig. 3 Vertical variation of temperature and salinity at the sampling stations 1-13

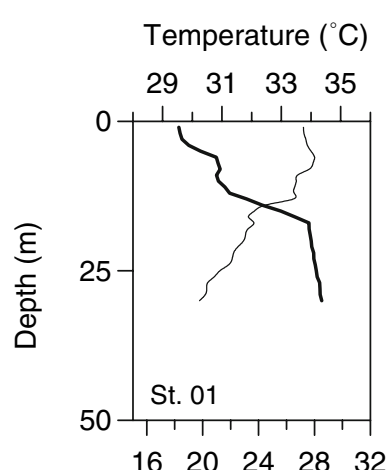

Temperature $\left({ }^{\circ} \mathrm{C}\right)$

Temperature $\left({ }^{\circ} \mathrm{C}\right)$

Temperature $\left({ }^{\circ} \mathrm{C}\right)$

$\begin{array}{llll}29 & 31 & 33 & 35\end{array}$
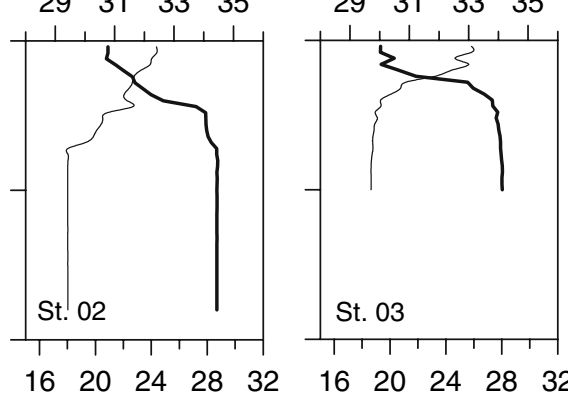

$\begin{array}{llll}29 & 31 & 33 & 35\end{array}$
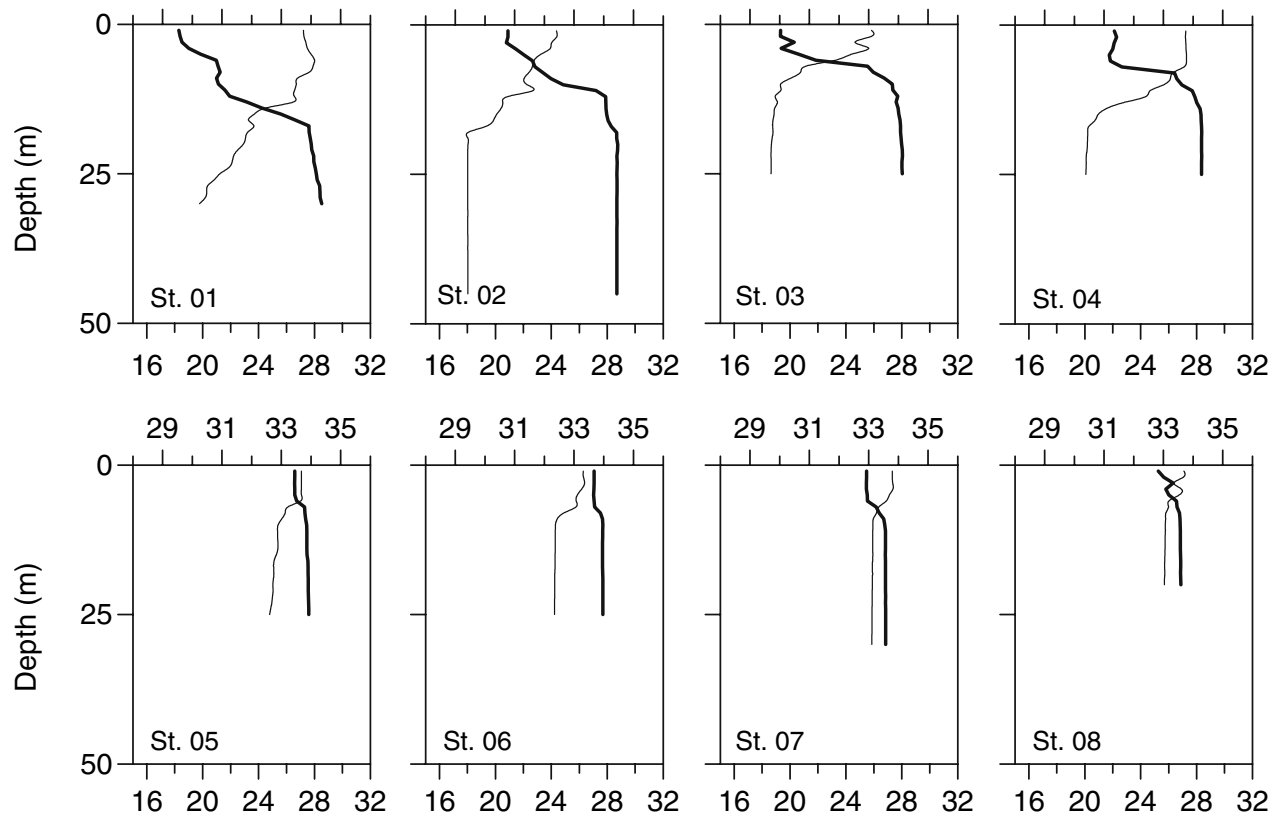

$\begin{array}{llll}29 & 31 & 33 & 35\end{array}$

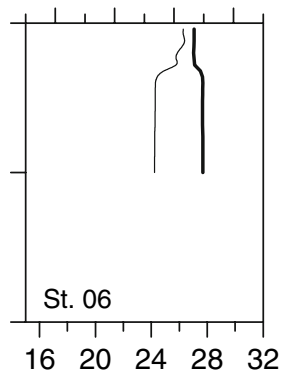

$\begin{array}{llll}29 & 31 & 33 & 35\end{array}$

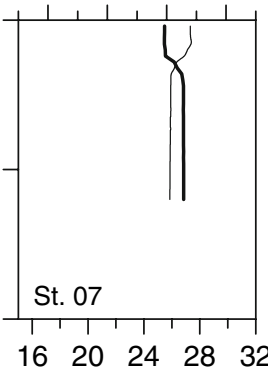

$\begin{array}{llll}29 & 31 & 33 & 35\end{array}$
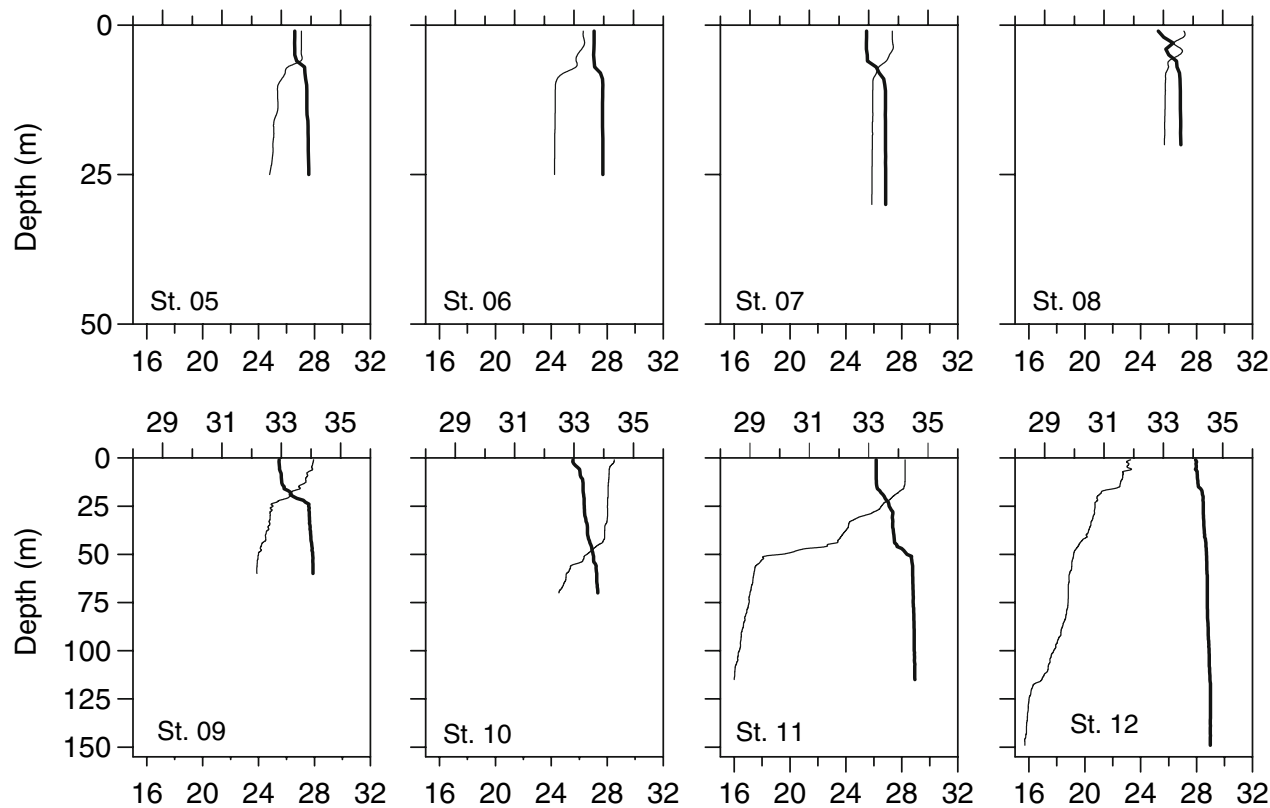

$\begin{array}{llll}29 & 31 & 33 & 35\end{array}$
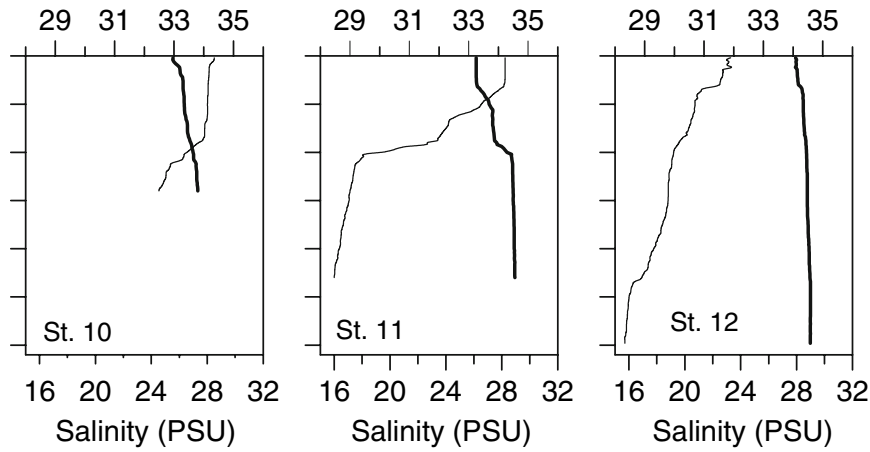

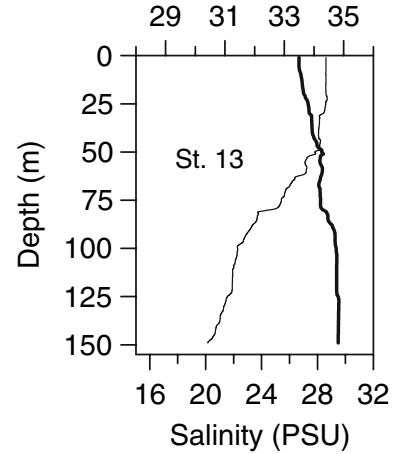

sampling stations can be grouped within five categories. First, station 9 (EMR) belongs to estuarine water. The runoff from the Minjiang River shows low salinity and higher temperatures. Here, the salinity can be lower than 29.0. Second, station 1 (EYR) grouped as the continental coastal water, is influenced by the Yangtze River with water resulting from a mixing of river runoff into the sea with a low-saline and high-temperature water mass. A third group, with stations 11 (NTS), 12 and 13 belongs to the ECS with mixed water from the KC and the Taiwan Strait Kuroshio branch water with the continental coastal water. Hence, salinity values range in the middle between these two. A fourth group with station 13 (KCR) being influenced by the Kuroshio surface layer water mass is characterized by high-temperature and high-salinity; the salinity can be higher than 34.2. A fifth group with low-saline and 
low-temperature water belongs to stations 3 and 4 . This water is formed by the Yangtze River mixed with continental coastal waters forming a long strip along the coast.

Hierarchical classification and identification of copepod assemblages

The different regional copepod communities in the East China Sea were distinguished using the first three cut-off levels of the dendrogram (Fig. 4): The first cut-off level separated the mainland China Shelf stations from the other stations in the NTS and the KCR. In the next hierarchical level, the NTS stations were separated from station 13 that was sampled for eight times during day and night in the KCR (Fig. 4). The last hierarchical level considered here allowed to split the Mainland China Shelf stations into two clusters: (1) the northern stations near the EYR, and (2) the southern stations near the EMR. The cluster analysis showed that the geographical variability in copepod composition is greater than the variability at the same stations over day and night periods. In fact, the four stations $(1,8,10$ and 13) that were sampled several times during day and night belong to four different clusters at the four-group hierarchical level (Fig. 4).

The different assemblages of copepod species corresponding to the different hierarchical levels discussed above are selected and shown in Fig. 5. For the first hierarchical subdivision in two groups, 40 species $(52 \%$ of the total set of species) were retained in these assemblages. The Mainland China shelf assemblage was characterised by the harpacticoid species Euterpina acutifrons, two calanoid species (Parvocalanus crassirostris and Acartia (Odonta- cartia) spinicauda), the poecilostomatoid species Corycaeus (Ditrichocorycaeus) affinis and two cyclopoid species (Oithona nana and Oithona rigida). The indicator values of all these species were larger than $70 \%$ and at maximum for this assemblage (Fig. 5). A second assemblage of NTS and the KCR was characterised by 27 species (Fig. 5), but for only three calanoid species (Acartia negligens, Clausocalanus furcatus and Paracalanus nanus) the indicator values were maximal and larger than $70 \%$. Additional 12 copepod species reached their maximal IndVal for this group (Fig. 5). In the next hierarchical level, the NTS stations were separated from the KCR stations and the IndVal of several species increased significantly and reached maximal values at this cut-off levels. The IndVals of both calanoid species Undinula vulgaris and Temora discaudata increased between the first and the second cut-off level from 67.21 and $76.24 \%$ to 89.48 and $84.69 \%$, respectively. These species are most characteristic for this assemblage. Even if the IndVal of Paracalanus nanus slightly decreased at the second hierarchical level, it remains high (86.73) to consider this species as being characteristic for the NTS region. The maximal values of IndVal in this group were reached for six additional copepod species, namely Pareucalanus attenuatus, Acrocalanus gracilis, Acrocalanus monachus, Paracalanus aculeatus, Calanopia minor and Corycaeus (Onychocorycaeus) pumilus (Fig. 5). The harpacticoid Macrosetella gracilis and the calanoid Lucicutia flavicornis showed the highest individual values for the KCR assemblage (Fig. 5).

The third cut-off level allowed separating the EYR assemblage indicated by nine species from the EMR assem-
Fig. 4 Hierarchical classification of the sampling sites for planktonic copepods during 15-29 July 2001 in the East China Sea. The characteristics of the sampling sites (depth, date and time) are shown in Table 1. The first three cut-off levels are indicated by dotted lines

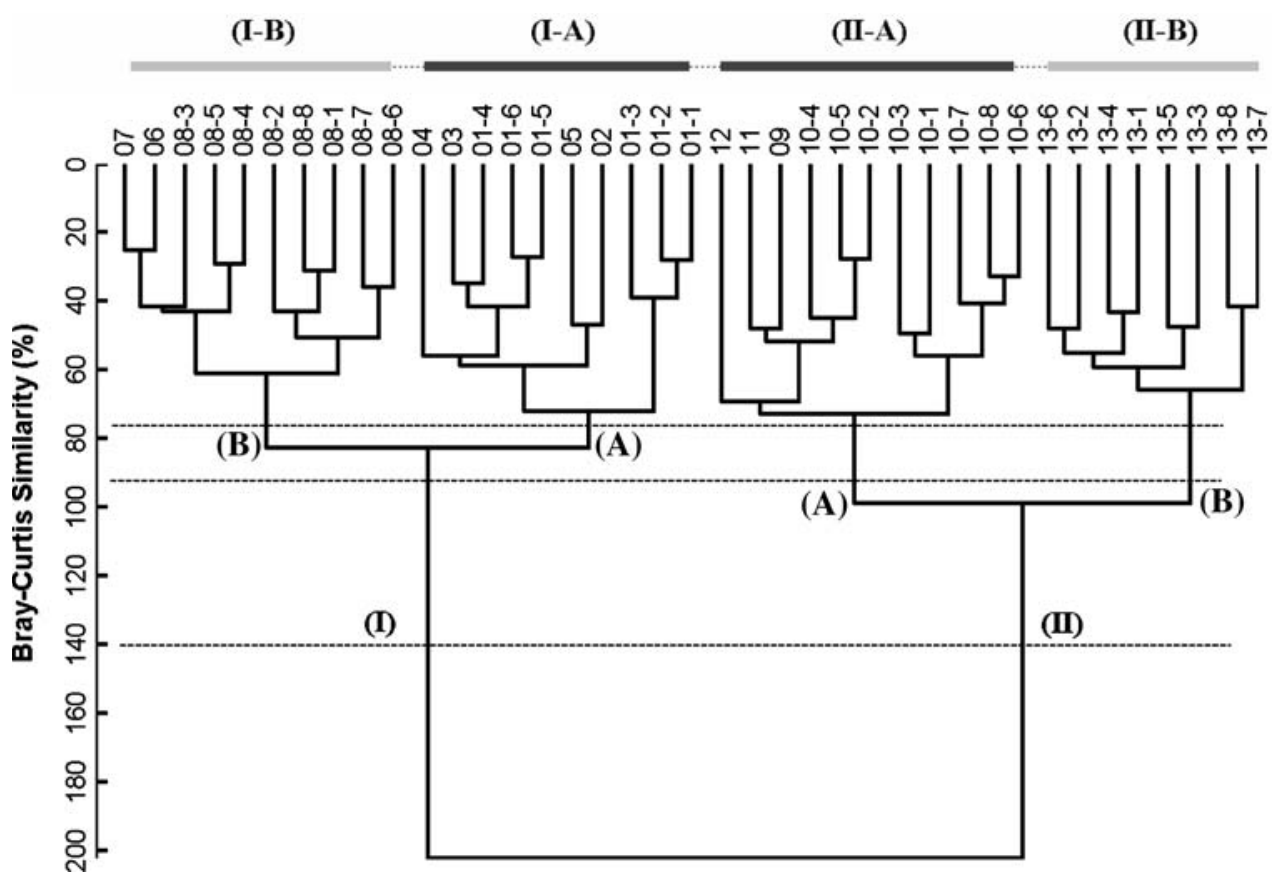



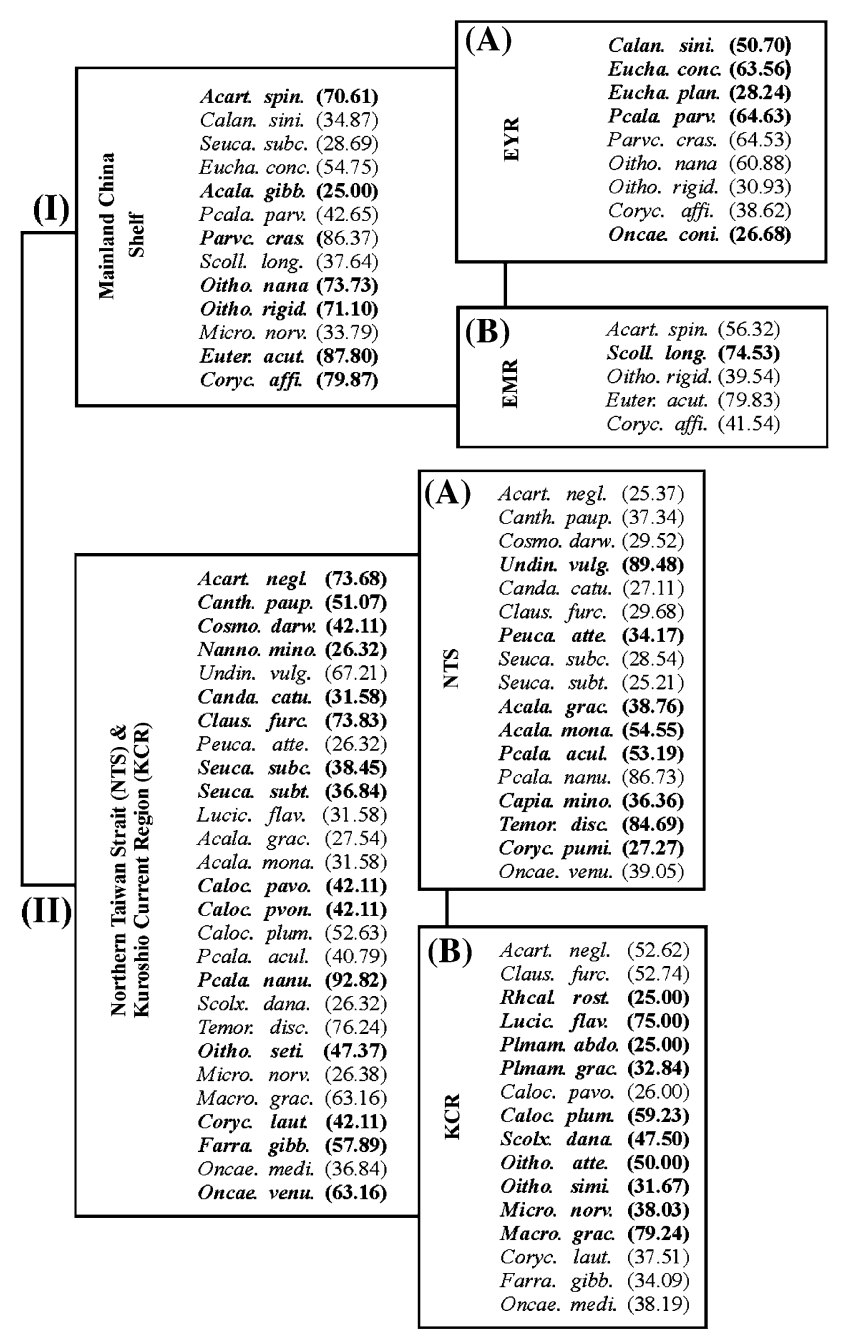

Fig. 5 Representation of the summer planktonic copepod assemblages in different regions in the East China Sea obtained from Fig. 4 (three cut-off levels). Species abbreviations shown in Table 2 are used to identify the different assemblages. The indicator values are shown between parentheses; maximal values in bold

blage indicated by five species (Fig. 5). From the indicator species of the EYR assemblage, we distinguish the northern species, i.e. Calanus sinicus and Euchaeta concinna. The species Scolecithricella longispinosa and Euterpina acutifrons are most characteristic of the EMR assemblage (Fig. 5). The spatial pattern of most indicator species for each copepod assemblage is provided in Fig. 6. The small harpacticoid Euterpina acutifrons (Fig. 6a) is characteristic for neritic assemblages occurring at all shallow stations along the China shelf. Its pattern of distribution is opposed to the one of P. nanus (Fig. 6b) at the deeper stations 9-13. However, the highest abundance of $P$. nanus was observed in the Taiwan Strait. For the higher resolution assemblages, the northern distribution of Paracalanus parvus (Fig. 6c) is clearly opposed to the spatial pattern of Scolecithricella longispinosa (Fig. 6d), being highly abundant at station 8 . Undinula vulgaris (Fig. 6e) shows a low abundance in northern Taiwan at this time of the year, whereas Macrosetella gracilis (Fig. 6f) is more abundant at the Kuroshio Current station. The high variability in the abundance of some species shown in Fig. 6 can be explained by a daynight difference in their abundance. It is worth noting that this shows a typical spatial distribution though. The indicator species of NTS and KCR (see Fig. 5) are characterised by higher abundances at stations 9 and 13, respectively.

The patterns of abundance and diversity of copepods in the area studied are provided in Fig. 7. Copepod numbers were highest at the northern China shelf station 3 $\left(12,901.20\right.$ individuals $\left.\mathrm{m}^{-3}\right)$ and lowest at station 12 (680.70 individuals $\mathrm{m}^{-3}$ ), whereas the Shannon-Wiener diversity index remained similar along the coastline of China. Species richness and diversity indices increase from the NTR to the KCR. The richness index values varied from a lowest value of 0.64 at station 2 to the highest values at station $10(2.88 \pm 0.33)$. It can thus be concluded that copepod species diversity is highly influenced by the complex hydrographic regime in this region. The ShannonWiener diversity index varied from 1.37 at station 2 to $2.78 \pm 0.13$ at station 13 , diversity showing highest values at KCR. The evenness index varied from 0.63 at station 9 to $0.92 \pm 0.03$ at station 13. No other significant difference was found between stations.

\section{Discussion}

The present study provides a correlation between copepod abundances and sampling sites. Cluster results indicate that copepod species distribution patterns were correlated with water masses in the southwest ECS area. A similar study by Shih and Chiu (1998) found that the abundance of copepods was higher in the north of Taiwan than in coastal waters or areas influenced by the KC. The present results confirm that different water masses are characterized by different copepod compositions from the $\mathrm{KC}$ area to the north of Taiwan. Our data support the notion that copepod distribution patterns correspond to water masses reported by Shih and Chiu (1998), Shih et al. (2000), Hwang et al. (2004), Hwang and Wong (2005), and Hwang et al. (2006).

The present study found copepod densities several times higher than reported by Shih and Chiu (1998) from the southern East China Sea and by Shih et al. (2000) in upwelling regions of the western North Pacific. We explain this with the smaller mesh sized zooplankton nets and different sampling depths applied in the present study. A smaller mesh size $(100 \mu \mathrm{m})$ clearly caused an increase of retrieved copepod abundances in the present study. Shih and Chiu (1998) and Shih et al. (2000) used 500 and $333 \mu \mathrm{m}$ mesh size plankton nets for their studies, respectively. Such differences in sampling design could be 
Fig. 6 Spatial patterns of indicator species for the sampling stations 1-13
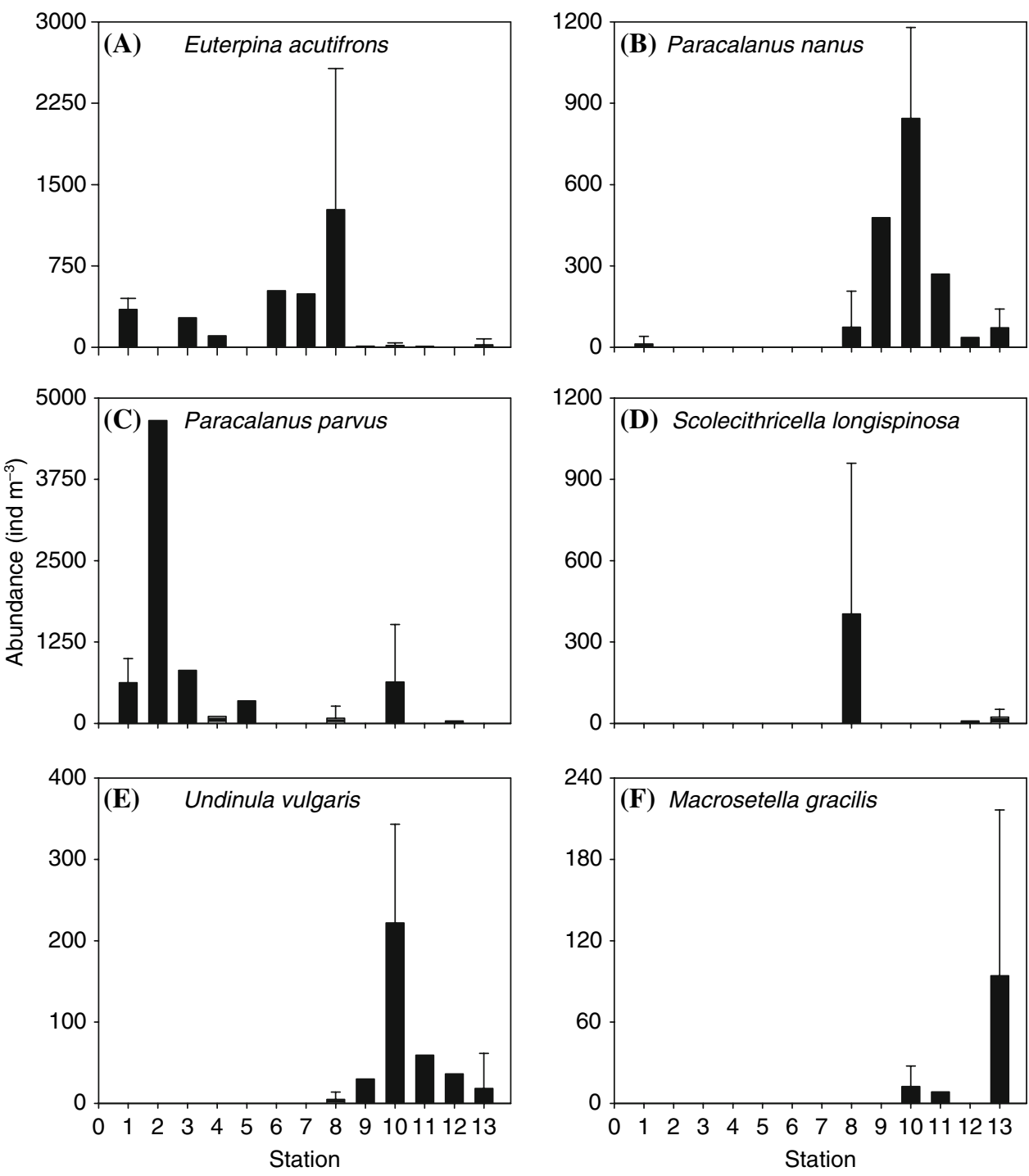

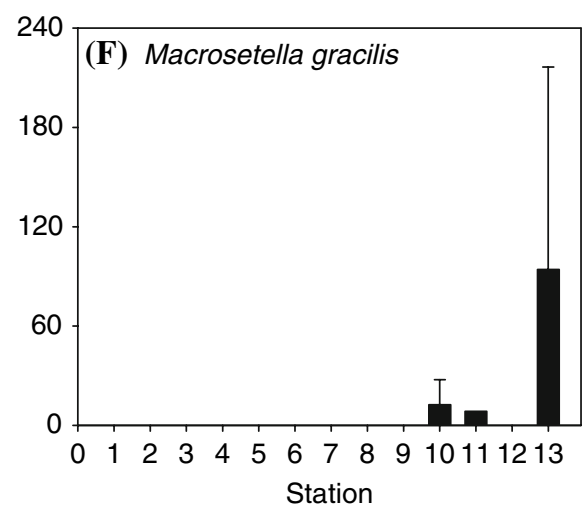

responsible for the variations in the densities obtained, and for the size composition of copepods. The use of a $100 \mu \mathrm{m}$ mesh allowed the retrieval of several smaller mesozooplanktonic copepod species (i.e. species belonging to: Paracalanus, Clausocalanus, Acartia, Oithona, Oncaea, Corycaeus) that are known to be abundant, particularly in coastal waters (Turner 2004). Accordingly, copepod abundances in the present study were much higher than in several long-term studies (Hwang et al. 2006). Different sampling depths and sampling times affect copepod densities and species occurrences (Shih et al. 2000). In addition, change copepod abundance and composition with the diurnal migrations of plankton (Lo and Hwang 2000; Shih et al. 2000). Our samples are from shallower waters than those of Shih and Chiu (1998) and Shih et al. (2000), resulting in higher copepod abundances.

The present results of hierarchical classification of the ECS samples show that group similarity is positively correlated with the geographic distance of stations to the main- land of China. Shih and Chiu (1998) observed that relative similarity is higher at stations nearby the mainland of China and lower at coastal stations compared to the $\mathrm{KC}$ (Hsieh et al. 2004). Hsieh and Chiu (1997) studied copepod assemblages in estuarine and coastal waters and found the species composition to be correlated with the geographic location of sampling stations. The properties of our stations 9-12 may be related to the fact that these stations are located close to upwelling areas. This could explain the different copepod composition relative to that of stations north of the Taiwan transect line, and the separation into the same group (group II-A, Fig. 4) by the cluster approach. Stations 1-8 belong to coastal waters from the EYR to the EMR area (Fig. 1). A similar cluster analysis for copepod composition confirms that these stations belong to the same group (group I, Fig. 4). Two different groups can be separated: a northern coastal group of stations (stations 1-5, group I-A), and a southern coastal group of stations (stations 6-8, group I-B). The stations at the northern coast close to EYR 
Fig. 7 Copepod abundance, species richness, Shannon-Wiener diversity index and Pielou's evenness index during 15-29 July 2001 in the East China Sea. Only those stations sampled for several times during the day and at night are provided with error bars (=standard deviations)

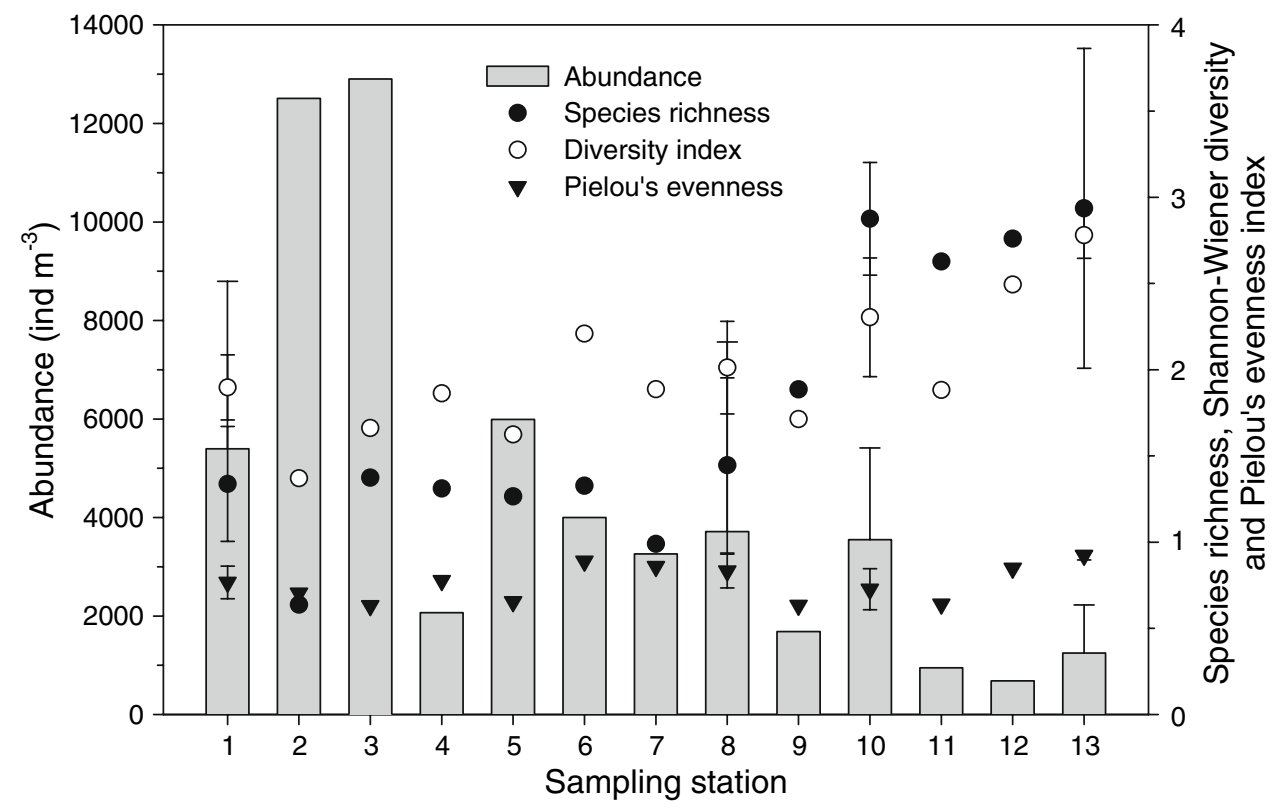

and the stations of the southern coast group close to EMR belong to different water masses, which are indicated by different copepod assemblages. We conclude from AVHRR temperature images (Fig. 2a) that the EYR intrusion waters cannot affect the EMR area. At the first hierarchical level, NTS and KCR stations constituted a single assemblage composed of 77 different copepod species (Fig. 4). For these areas close to Taiwan it is possible to compare our findings with other studies from the northern coast of Taiwan. In the present study, the number of species observed in the southwest East China Sea area is higher than that recorded by Hwang et al. (1998) from the coastal waters off the northern tip of Taiwan in summer where these authors identified 25 species of calanoid copepods. Dominant species that were found at all stations were Acrocalanus gracilis, Canthocalanus pauper, Temora discaudata. Temora turbinata and Undinula vulgaris. Wong et al. (1998) identified 37 species of calanoid copepods near a nuclear power plant area in northern Taiwan and found A. gracilis as being dominant there (see also Hwang et al. 2004). The main copepod species found by Hwang et al. (1998) and Wong et al. (1998) in the summer season in northern Taiwan were also found in the present study. Other reports from the northern Taiwan Strait (Hsieh and Chiu 2002) and the upwelling area of northern Taiwan (Lo et al. 2004) confirmed higher species numbers than in the present study. A 5 -year study by Hwang et al. (2006) showed similar results. Here, a total of 110 copepod species were reported and their distribution patterns were related to the NE and SW monsoons (Hwang et al. 2006). Diversity estimates of copepod species in other studies of this geographical sector are very variable due to different seasons or years making a comparison with previous studies difficult. The present study provides species numbers higher than those in coastal waters of southwest Taiwan (67 species by Lo et al. 2001), but lower than those in the northern South China Sea (78 species by Hwang et al. 2000).

Reports of species composition show a remarkable variability at temporal scales, such as seasonal or monthly differences (Hsieh and Chiu 1997). Comparing the species composition found during the present study with those of Shih and Chiu (1998), Chen and Zhang (1965) and Chen et al. (1974), all copepod species found in previous studies were claimed to be characteristic for the southern East China Sea.

All members of the copepod communities identified in the present study were found in reports of other studies from the ECS (Chen and Zhang 1965; Chen et al. 1974; Shih and Chiu 1998). In addition, copepod communities from the ECS were dominated by calanoid species that were reported from several localities around Taiwan (Hsieh and Chiu 1997, 2002; Hwang et al. 1998, 2000; Lo and Hwang 2000; Lo et al. 2001; Shih and Chiu 1998; Shih et al. 2000; Tseng 1975, 1976; Wong et al. 1998; Hwang 2004; Hwang et al. 2006; Dur et al. 2007). According to the classical copepod survey by Shih and Young (1995), almost all species reported from adjacent seas of Taiwan are wide spread in the East and the South China Sea. However, the majority of recorded copepod species were not widely distributed, with 13 species found in only one sampling area. No species occurred at all stations and in more than $70 \%$ of the samples. The calanoid $P$. crassirostris with a $69.23 \%$ occurrence ratio and an average abundance of 626.88 individuals $\mathrm{m}^{-3}$ was the most frequently occurring and most abundant species in all samples. Lo et al. (2004) surveyed only the upwelling area of northern Taiwan and 
found that $P$. crassirostris belonged to one of the three most abundant species. Our data confirms this species to be dominant in northern Taiwan. Its dominance on the coastal shelf extends to northern Taiwan where it still shows high abundances. Through station 13 in the upwelling area, the density of $P$. crassirostris decreases and disappears completely at KCR. We suppose that this species prefers low salinities and is wide spread along the coast of the mainland of China and in the southwest ECS. The calanoid P. crassirostris can be an important indicator-species in the ECS. The relative occurrence of copepod species in the present study was similar to that found during April in the southern ECS north of Taiwan (Shih and Chiu 1998). Three species, C. sinicus, E. rimana, and $P$. aculeatus were the most abundant species among the top 20, corresponding to the results of the present study. This demonstrates the dominance of these three copepod species from April to July in this area. It is reasonable to assume that the composition of copepod assemblages follows a seasonal shift, primarily affected by the TS Current and annual monsoonal changes (Chen 1992; Chen et al. 1998). The dominant species of the NTS station were similar in their temporal occurrence and locations to these previous reports.

There are some results of the present study that deserve to be emphasized here, e.g., the highest copepod abundance during the present survey occurred at stations 3 and 4 along the coast. Water mass characteristics at these two stations were: low salinity and low temperature (Fig. 2). Major contributing species were $P$. parvus, $P$. crassirostris and $O$. nana. We speculate these species to tolerate low salinity and low temperature conditions (Chen and Zhang 1965). However, these species were also dominant in coastal areas and occurred there at high temperature and low salinities (Chen and Zhang 1965). In the present study, C. sinicus appeared at all stations except the KCR station. This species is characteristic of the East China Sea as reported in previous papers (Chen 1992; Shih and Chiu 1998; Shih et al. 2000; Souissi et al. 2004; Hwang and Wong 2005). Chen (1992) argues that $C$. sinicus is one of the seven most dominant copepods in the ECS continental waters. Shih and Chiu (1998) found it to be dominant in the ECS and few individuals could be found in the Kuroshio region, which confirmed the observation of Chen (1992). When Shih et al. (2000) surveyed an upwelling area (near our station 13), they rarely found $C$. sinicus in their samples. Our result confirms that $C$. sinicus is abundant in the ECS, rare in midway stations and absent near the Kuroshio Current (Hwang and Wong 2005; Hwang et al. 2004, 2006). Considering that the Kuroshio Current flows along the east coast towards the north to Japan, we suppose that water masses begin to mix and exchange with the ECS water mass edge in the northeast of the Taiwan upwelling regions. That might be the reason why Shih and Chiu (1998) found
C. sinicus distributed in the Kuroshio Current area of the warm water mass, at a station north of our KCR station.

Acknowledgments We thank Prof. G. C. Gong and Prof. J. Chang for providing us with the opportunity to collect plankton samples in the South East China Sea. We also appreciate the assistance of the captain and technicians of Ocean Research Vessel I in the collection of zooplankton during cruise 618 . The present work is a contribution to the bilateral project CNRS (France)-NSC (Taiwan) n 17473.

\section{References}

Anneville O, Souissi S, Ibanez F, Ginot V, Druart JC, Angeli N (2002) Temporal mapping of phytoplankton assemblages in Lake Geneva: annual and interannual changes in patterns of succession. Limnol Oceanogr 47:1355-1366

Ashjian CJ, Davis CS, Gallagher SM, Alatalo P (2005) Characterization of the zooplankton community, size composition, and distribution in relation to hydrography in the Japan/ East Sea. Deep Sea Res Part II 52:1363-1392

Berasategui AD, Menu Marque S, Gomez-Erache M, Ramirez FC, Mianzan HW, Acha EM (2006) Copepod assemblages in a highly complex hydrographic region. Estuar Coast Shelf Sci 66:483-492

Chang J, Chiang KP, Gong GC (2000) Seasonal variation and crossshelf distribution of the nitrogen-fixing cyanobacterium, Trichodesmium, in the southern East China Sea. Cont Shelf Res 20:479-492

Chang J, Shiah FK, Gong GC, Chiang KP (2003a) Cross-shelf variation in carbon-to-chlorophyll $a$ ratios in the East China Sea. Deep Sea Res Part II 50:1237-1247

Chang J, Lin KH, Chen KM, Gong GC, Chiang KP (2003b) Synechococcus growth and mortality rates in the East China Sea: range of variation and correlation with environmental factors. Deep Sea Res Part II 50:1265-1278

Chen QC (1992) Zooplankton of China Seas (1). Science Press, Beijing

Chen HY, Chen LYL (1992) Quantity and Quality of summer surface net zooplankton in the Kuroshio current-induced upwelling northeast of Taiwan. TAO 3:321-334

Chen QC, Zhang SZ (1965) The planktonic copepods of the Yellow Sea and the East China Sea. I. Calanoida. (In Chinese, with English abstract). Stud Mar Sinica 7:20-133

Chen QC, Zhang SZ, Zhu CS (1974) On Planktonic copepods of the Yellow Sea and the East China Sea. II. Cyclopoida and Harpacticoida (In Chinese, with English abstract). Stud Mar Sinica 9:27100

Chen QC, Hwang JS, Wong CK (1998) Characteristics of zooplankton in northern coastal Taiwan during the NE monsoon initial period (In Chinese, with English abstract). J Oceanogr Taiwan Strait 17:87-90

Chiang KP, Kuo MC, Chang J, Wang RH, Gong GC (2002) Spatial and temporal variation of the Synechococcus population in the East China Sea and its contribution to phytoplankton biomass. Cont Shelf Res 22:3-13

Dufrêne M, Legendre P (1997) Species assemblages and indicator species: the need for a flexible asymmetrical approach. Ecol Monogr 67:345-366

Dur G, Hwang JS, Souissi S, Tseng LC, Wu CH, Hsiao SH, Chen QC (2007) An overview of the influence of hydrodynamics on the spatial and temporal patterns of the calanoid copepod communities around Taiwan. J Plankton Res 29:97-116

Gong GC, Chen YL, Liu KK (1996) Chemical hydrography and chlorophyll a distribution in the East China Sea in summer: implications on nutrient dynamics. Cont Shelf Res 16:1561-1590 
Gong GC, Shiah FK, Liu KK, Wen YH, Liang MH (2000) Spatial and temporal variation of chlorophyll a, primary productivity and chemical hydrography in the southern East China Sea. Cont Shelf Res 20:411-436

Gong GC, Chang J, Liang MH (2001) A photosynthetic-irradiance model for the upwelling region northeast of Taiwan and its application to the East China Sea. J Geophys Res 106:19957-19968

Gong GC, Liu GJ (2003) An empirical primary production model for the East China Sea. Cont Shelf Res 23:213-224

Hsieh CH, Chiu TS (1997) Copepod abundance and species composition of Tanshui river estuary and adjacent waters. Acta Zool Taiwan 8:75-83

Hsieh CH, Chiu TS (2002) Summer spatial distribution of copepods and fish larvae in relation to hydrography in the northern Taiwan Strait. Zool Stud 41:85-98

Hsieh CH, Chiu TS, Shih CT (2004) Copepod diversity and composition as indicators of intrusion of the Kuroshio Branch Current into the northern Taiwan Strait in spring 2000. Zool Stud 43:393-403

Huys R, Boxshall GA (1992) Copepod evolution. The Ray Society, London

Hwang JS, Chen QC, Wong CK (1998) Taxonomic composition and grazing rate of calanoid copepods in coastal waters of northern Taiwan. Crustaceana 71:378-389

Hwang JS, Chen QC, Lo WT, Chen MP (2000) Taxonomic composition and abundance of the copepods in the northern South China Sea. Natl Taiwan Mus Spec Publ Ser 10:101-108

Hwang JS, Wong CK (2005) The China Coastal Current as a driving force for transporting Calanus sinicus (Copepoda: Calanoida) from its population centers to waters of Taiwan and Hong Kong during the winter northeast monsoon period. J Plankton Res 27:205-210

Hwang JS, Souissi S, Tseng LC, Seurong L, Schmitt FG, Fang LS, Peng SH, Wu CW, Hsiao SH, Twan WH, Wei TP, Kumar R, Fang TH, Chen QC, Wong CK (2006) A 5-year study of the influence of the northeast and southwest monsoons on copepod assemblages in the boundary coastal waters between the East China Sea and the Taiwan Strait. J Plankton Res 28:943-958

Hwang JS, Tu YY, Tseng LC, 10 additional authors (2004) Taxonomic composition and seasonal distribution of copepod assemblages from waters adjacent to nuclear power plant I and II in northern Taiwan. J Mar Sci Technol 12:380-391

Lan YC, Shih CT, Lee MA, Shieh HZ (2004) Spring distribution of copepods in relation to water masses in the northern Taiwan Strait. Zool Stud 43:332-343

Liu KK, Tang TY, Gong GC, Chen LY, Shiah FK (2000) Cross-shelf and along-shelf nutrient fluxes derived from flow fields and chemical hydrography observed in the southern East China Sea off northern Taiwan. Cont Shelf Res 20:493-523

Lo WT, Hwang JS (2000) The diel vertical distribution of zooplankton in the northeastern South China Sea. Natl Taiwan Mus Spec Publ Ser 10:59-73
Lo WT, Hwang JS, Chen QC (2001) Identity and abundance of surface-dwelling, coastal copepods of southwestern Taiwan. Crustaceana 74:1139-1157

Lo WT, Shih CT, Hwang JS (2004) Diel vertical migration of the planktonic copepods at an upwelling station north of Taiwan, western North Pacific. J Plankton Res 26:89-97

Shahidu Islam Md, Ueda H, Tanaka M (2006) Spatial and seasonal variations in copepod communities related to a turbidity maximum along the Chikugo estuarine gradient in the upper Ariake Bay, Japan. Estuar Coast Shelf Sci 68:113-126

Shiah FK, Gong GC, Chen CC (2003) Seasonal and spatial variation of bacterial production in the continental shelf of the East China Sea: a synthesis of controlling mechanisms and potential roles in carbon cycling. Deep Sea Res Part II 50:1295-1309

Shih CT, Chiu TS (1998) Copepod diversity in the water masses of the southern East China Sea north of Taiwan. J Mar Syst 15:533-542

Shih CT, Young SS (1995) A checklist of free-living copepods, including those associated with invertebrates, reported from the adjacent seas of Taiwan. Acta Zool Taiwan 6:65-81

Shih CT, Hwang JS, Huang WB (2000) Planktonic copepods from an upwelling station north of Taiwan, western north Pacific. Natl Taiwan Mus Spec Publ Ser 10:19-35

Souissi S, Hwang JS, Tseng LC, Seuront L, Schmitt FG, Chen QC (2004) Use of the copepod Calanus sinicus as a tracer of cold-water intrusions in the northern coast of Taiwan. Geophys Res Abstr 6:5051

Souissi S, Ibanez F, Ben Hamadou R, Boucher J, Cathelineau AC, Blanchard F, Poulard JC (2001) A new multivariate mapping method for studying species assemblages and their habitats: example using bottom trawl surveys in the Bay of Biscay (France). Sarsia 86:527-542

Tan TH (1967) On distributions of copepods in the surrounding waters of Taiwan. Rep Inst Fish Biol Minist Econ Aff Natl Taiwan Univ 2:14-20

Tseng WY (1975) Planktonic copepods from the waters off Tansui. (In Chinese). Bull Taiwan Fish Res Inst 25:1-44

Tseng WY (1976) Supplementary report on planktonic copepods from the waters off Tansui, Taiwan (In Chinese, with English abstract). Bull Taiwan Fish Res Inst 25:105-112

Turner JT (1998) Feeding ecology of marine copepods: an overview of recent studies and emerging issues. Natl Taiwan Mus Spec Publ Ser 10:37-57

Turner JT (2004) The importance of small planktonic copepods and their roles in pelagic marine food webs. Zool Stud 43:255-266

Wong CK, Hwang JS, Chen QC (1998) Taxonomic composition and grazing impact of Calanoid Copepods in coastal waters near nuclear power plants in northern Taiwan. Zool Stud 37:330-339

Zheng Z, Zhang S, Li S, Fang JC, Lai RQ, Zhang S, Li SQ, Xu ZZ (1965) Marine planktonic copepods of China, vol 1. (In Chinese). Shanghai Science and Technology Press, Shanghai

Zheng Z, Li S, Li SQ, Chen BY (1982) Marine planktonic copepods of China, vol 2 (in Chinese). Shanghai Science and Technology Press, Shanghai 